\title{
UNITY AND IDENTITY AFTER ASHURA in ISLAMic History
}

\author{
Habibollah Babaei \\ Department of Islam and West Studies, \\ Islamic Science and Culture Academy, Qom, I. R. Iran
}

\begin{abstract}
Remembrance of Imam Husayn's self-sacrifice in Ashura has created unity among Muslims (unity in movements, unity in communities, and eventually unity in identity) during their long history after Ashura. In the main, Husayn's sacrifice in Karbala did not cause the confilict between Sunni and Shi'a, rather it resulted in unity and social solidarity in several areas including social communities, political movements and religious collective identity. Even if the sacrificial martyrdom took serious disaster, the result was really effective in Sunni and Shi'a Muslims relationships, as well as, Muslim and non-Muslim relations where they (Muslims and Christians) lived in multi-religious communities such as Lebanon, Iran, and India. Thus, it would not be surprising to believe that remembring such celestial sacrifice can perform the task of redemption from terrestrial confilicts and clashes in the world such as ours.
\end{abstract}

Keywords: unity, identity, suffering, self-sacrifice, Imam Husayn, remembrance

\section{Introduction}

At first glance, it seems that Husayn's tragedy in Ashura was the controversy through which clashes took place between Sunni and Shi'a several times in the Islamic history. Therefore, the revival of this historical episode or the remembrance of this incident will have potency to make the same conflict in the future. A few Sunni scholars such as Ibn Khaldoon argued for this kind of standpoint. But at a deeper glance, the martyr of Ashura stood up against

Corresponding author: habz109@gmail.com 
divisive factors which were going to eliminate Sharia as a fundamental cornerstone for collective religious unity and identity among Muslims. Likewise, this bloody movement did not result in denigration; instead, it brought out dignity and honor for Muslims against Bani Umayyah and Bani Abbas tyrannies. Many Sunni and Shi'a scholars argued in favour of this kind of opinion and theory. Based on a later notion, I will argue through this paper that the memory of Husayn's martyrdom has enough power and force not only to create social solidarity, but also to protect dignity and honor by resisting new evils and devils in the modern context such as ours (see: Bābāei 2010).

Husayn's movement in Karbala created real unity not only between Arab and Ajam people in Shi'a community (in Mokhtar's uprising), but also between Shi'a and Sunni people against Bani Umayyah tyrannies. In fact, the tragedy of Karbala proposed a model and measure for morality and humanity to Muslims' mind through which they were able to find and follow common righteousness in wicked circumstances. Husayn ibn Ali displayed an inclusive divine self through which he brought both Shi'a and Sunni under common shelter and identity. By this model of self-sacrifice, Imam Husayn drew non-Muslims' (Hindu and Christian people) attention to it and made them see it as a powerful factor in creation of sacred sacrificial identity.

However, by highlighting inclusivity of Husayn's self-sacrifice and his unifying role, I do not mean to say that every kind of solidarity in Muslim history emerged from Imam Husayn's tragedy in Karbala. Undoubtedly, unity and identity of Muslims after Prophet Muhammad arose from different causes and grounds (Āeinehvand 1988: 8). What I mean by the unifying role of Imam Husayn is his crucial and decisive role in creation of love of Ahlulbayt (Mawaddat fi al-Qurba) ${ }^{1}$ as an exclusive way in the Qur'an for realization of solidarity and commonality among Muslim Ummah (Qur'an 2:213). Therefore, though I agree with those who say that identity of Shi'a people started from Ashura day (Ja'fari 1999: 250), I think it is more accurate to state that not only Shi'a identity but Islamic character was formulated (or revived) from Ashura and has lasted up to day by it being remembered.

My major approach here, in this article, will be historical, although the historical approach has its own limitation when dealing with multidimensional issues such as Karbala. Therefore, I will go beyond historical records and try to set forth some theological features of this tragedy as well as to examine the nature and results of Karbala tragedy over Muslims history.

Now, before I proceed, I find it worth asking an introductory question here. Who started the fighting and dichotomy between Muslims Ummah? Was it Yazid or Imam Husayn? The answer to this question is of fundamental

1 "Say: I do not ask of you a wage for this, except love for the kinsfolk" (Qur'an 42: 23). 
importance for conceiving Husayn's manner even against such an aggressive tyranny as Yazid's was.

\section{The Primary Cause of Conflicts after Mu'awiyah}

Who caused the abyss among Muslims? Was it Yazid (ibn Mu'awiyah) or Husayn (ibn Ali)? In order to give an answer to this question we should never lose sight of the following:

a) All Shi' ite historians along with many Sunni scholars agree that Yazid never cared about nor respected Islamic law (sharia). Yazid disregarded and ignored many essential Islamic principles. According to Islamic thinking, committing such a flagrant violation is regarded as a kind of apostasy. In a deeper sense, the commitment to Islamic sharia is the minimum religiosity in Islam. Indeed, this minimum of religiosity constitutes the base of social solidarity and collective identity through which Muslim Ummah comes up. Based on this point, abandoning of Islamic sharia is equal to the rejection of solidarity, just as reviving of sharia is, in fact, reviving of solidarity and Islamic identity. Now, Husayn, according to his spiritual mission, had to stand up against this deep division among Muslims. Needless to say, although mystical and spiritual aspects of Islam had been abandoned by some provious caliphates, Islamic law (jurisprudence), as an external layer, was respected and protected. Therefore, Imams like Imam Ali, Imam Hasan and Imam Husayn himself, in ten years during Mu'awiah's government, tolerated Abubakr, Omar, Osman and even Mu'awiyah's authority, to preserve Muslim community and commonality. But, when this minimum aspect of Islam was disrespected and eliminated by Yazid ibn Mu'awiyah, Husayn stood up against him to protect Islamic Ummah from division and dichotomy (see: Al-Shaybāni 1994: 48). Therefore, Imam Husayn's revolution against Yazid was, in fact, a revolution against fragmentation and division.

b) Although Imam Husayn had to fight Yazid, he was not the one to start the war. When Kufians invited Imam to their home, he accepted, and when they left him alone, he decided to return to his own home (Medina). Imam Husayn addressed Tamim ibn Gahtabah and when he asked Imam why he kept hostility and hate, the latter responded to him (Gahtabah): Was it me who came to fight with you or was it you who came to fight with me? Was I the one to block the roads to you, or was it you who did that to me and who surrounded me and killed my brothers and adolescents? (see: Sāzimān Pazhūhesh va Barnāme Rizi Āmūzeshi 2001: 381-382). 
Based on the above stated points, the dichotomy among Muslims was not the result of Imam Husayn's movement. It was rather the wicked character of Yazid who threatened Imam, not after his departure from Medina, but before it and within Medina. Yazid ordered his agent, whose name was Walid ibn 'Utbah: "if Husayn does not give me allegiance, cut his head off and don't delay in doing that." A violent policy like that was the result of Bani Umayyah's strategy. Accordingly, it is wrong to say that Imam's movement was the example of riot (Fitnah) and corruption (Fasad) (Säeib 1997: 398), or saying that Husayn caused the devision among Muslim Ummah (Khizri Bak 1963: 198). This view is not only wrong, but absurd so that both Shi'a and Sunni scholars along with many others objected to this wrong judgement on Imam Husayn's movement (see: Yūsuf 1998: 426-430, Alāeli 1927: 348). If Imam Husayn had remained in Medina, he would have been killed by Yazid's forces. It was Imam's intelligence that made him come to the decision to leave Medina and to choose, himself, his own destiny, where he should be sacrificed, and in what effective way he should be the martyr to preserve his honor and humanity against Yazid and Yazidians.

\section{Unity of Muslims after Ashura}

Unity after Ashura (in the history of Islam), could be considered in three directions:

1) Unity in Muslim movements after Ashura;

2) Unity in Muslim communities (including Shi'a and Sunni societies);

3) Unity in Muslim identity and character.

Each of these three cases of unity should be considered and analyzed to find out how Imam's bloody martyrdom formed a sort of unity and solidarity over the history of Islam.

I

Unity in Movements after Ashura

Although there were several movements after Ashura, Tawwabin (Repentant Muslims) and Mokhtar movements differed widely from other movements, such as Fakh rising (169/786), because they happened soon after Ashura with the same generation, within the same circumstances, and against the same opponents. Those movements could be best case studies to consider whether Husayn's movement created the division between Muslim Ummah or not. If Husayn's martyrdom had created dichotomy and disturbance or 
riot (fitnah), it would have arisen immediately after Ashura in the same epoch, while this bloody movement made unity among various Muslims against Bani Umayyah oppressors.

It should be recalled that, although those two movements were unlike in their aim and strategies, they had identical force in the creation of unity and affiliation. Tawwabin's aim was atonement from their sin in leaving Imam $\mathrm{Hu}$ sayn alone after they invited him, and Mokhtar's purpose was punishment of murderers of Imam and revenge on them. Solidarity that had been created by Tawwabin was sacrificial by hundered old leaders (more than 60 years old) of Arab tribes (Ja'fari 1999: 262). This kind of solidarity was really amazing and incredible when Umawi tyrannies renewed old tribal confilicts and frictions among Arab tribes. Solidarity of a hundred adults and their thousands of followers played a distinctive role in the creation of the unity-model amid various tribes in the South (Yaman) and North and central areas of Arabs. This became feasible only through the remembrance of the perfect self-sacrifice that is implemented by Imam Husayn in Karbala. However, whether or not Tawwabin had the best strategy in the fighting against Yazid, they were certainly inspired and encouraged just by remembrance of Imam Husayn's tragedy (ibid.: 263).

I believe this sort of atonement on which unity of various Muslim tribes had been built was extremely distinctive and archetypical repentance over whole human history (see: Tabari 1987: 585-588). It is worth noting that, if there had been no such bloody repentance by Tawwabin, and if there had been no Muslim mourning over the post-Ashura history in Islamic world, it would have ended in historical denigration of Muslim people as it was the case with Isreali nation when they abandoned their prophet and accepted Samaritan as an idol.

The same kind of unity was created in Mokhtar movement as well. Unity and solidarity in this camp was not among Arab leaders, but among Arab and Persian people (Mawali). Fars people and their association with Arabs was one of the most significant organizations which occurred through the consideration of Imam Husayn's bloody tragedy (by saying ya la sarat al-Husayn). Although there are disputes among Muslim scholars over Mokhtar's revolution, his followers (including Arab and Ajam) were inspired by Imam Husayn and made an example for unique Ummah at the time.

It should never be lost from sight that though Mokhtar had a serious role in the vengeance of Imam Husayn's blood, a lay person (I mean someone who is not Imam) like as him was not able to compensate for the sacred perfect blood of Husayn's by killing people such as Shimr, Khooli, and Ibn Ziyad. That is, the historical blood that bled from Husayn's body requires historical revenge that was beyond Mokhtar's ability. In other words, to clear the wronged blood of Imam Husayn from the land is something that will 
happen, according to Shi' ite beliefs, and be done by no other than Imam Mahdi (twelfth Imam) as a historical revenger at the end of the world.

II

\section{Unity in Islamic Communities}

Community based on mourning for Husayn was not confined to Shi' ite community (like Fatimiyyun - Ismaeili Shi'a - in Egypt who made Husayniyyah in Cairo) (Ali 1938: 509). ${ }^{1}$ It was inclusive of Sunni communities as well. ${ }^{2}$ Imam Husayn's tragedy constructed several serious unities and communities so that some tyrants such as Mutawakkil Abbasi ordered their soldiers (in 237/847) to destroy Imam's shrine (see: Majlisi 1983: 396-405, Qomi 2004: 327-328). Also, the Sunni people, in spite of pressures ${ }^{3}$ of tyrants such as Hārūn al-Rashid, formed several centers through the mourning for Imam Husayn. This kind of grieving ceremonies for Husayn's suffering prevailed across Islamic history, not only in Bani Umayyah epoch, but also in Timoriyan government (782-911/1380-1505). The most important evidence for Sunni communication through the remembrance of Imam Husayn tragedy was realized in Andalusia among Sunni Muslims. Andulsia was far from Islamic territories and Muslims there were dominated by Umawian tyrannies (see: Macci 1997: 41). Therefore, it seems too odd that Sunni people in such an area showed interest in Ahlulbayt and remembered Husayn's suffering in Karbala. ${ }^{4}$ When Hammudian Muslims ${ }^{5}$ engaged the government in Andalusia,

1 It is worth noting that business activities were not allowed in Ashura. All shopping centers were vacated, and sermonizers (maddah) with many people were wailing for Husayn and going to visit Ummu Kulsoom shrine (see: Muzaffar 1987: 188-189).

2 It should be noticed that the mournings for Imam Husayn flourished and get completed time after time epoch by epoch. It started from Shi'ite Imams' era, and then it got communal forms over Âli Būyah period, and in Mongol time, some places (Husayniyyah) were designated for mournings. After that, in Timūriyān epoch, the mournings got formal appearance and it was known as Rawzah. Next, in Safawiyyah age, the mourning for Imam Husayn blended with some rituals and special ceremonies and afterwards in Qajjār time Shabihkhāni was a prevalent ritual and eventually in the epoch of Islamic revolution in Iran it changed to the current form (Mazāhiri 2008: 293-295).

3 These kinds of pressures and attacks on Imam Husayn's shrine occurred frequently over the history by Vahhābiyya and others like Hārūn al-Rashid (see: Al-Tu’mah 1964: 262, AlAmin 1986: 628).

4 See poems of Ibn Jābir Andalusi about Ahlulbayt in Nafh al-Tayyib, Vol. 7, p. 359-367. This is coated from the introduction that is written by Abu Zayd for Al-Andalusi, Ibn Jabir (1985: 16).

5 Hammudian Muslims appeared after Umawi caliphate in Qurtubah/Cordoba (in Andalusia). Hammudians were generation of Idris ibn Hasan 'Alavi in the West of Islamic world. They were political conservative Shi'a who believed in Imama (Macci 1997: 53, 64). 
many poets wrote several poems about Ahlulbayt and Imam Husayn and many Sunnis performed ceremonies for Imam Husayn (ibid.: 100-101). ${ }^{1}$

The reason why Sunni people in Andalusia wrote, unexpectedly, such poems and performed such rituals has been interpreted in different ways. According to some Sunni scholars' view points, the reason for these poems at the end of Umayya epoch was the crisis Andalusia was suffering at the time. Based on this, the memory of Imam Husayn's suffering was compensation for their own disaster and frustration (ibid.: 102). Nonetheless, it is not clear why Sunnis remembered Imam Husayn's suffering, and not Osman's suffering, in such circumstances. Rasool Ja'farian wrote the following trying to answer this question: "it might be right to say that whoever suffers, they will take shelter from Mystical matters, but the main question that remains is why people mourn for Husayn's suffering, not others" (ibid.: 109). Whatever the reason, remembrance of Husayn's suffering points to proper grounds to consider Imam Husayn as a redemptive factor from their own suffering even in Andalusia and within Sunnis under Umawian tyrannies.

Needless to say, the focus on Husayn's suffering was affirmed by Sunni scholars as well as by others who were interested in the issue of Karbala. For instance, some Sunni scholars have written various historical texts about Husayn's martyrdom (Maqtal), like Maqtal Kharazmi, Rawzah al-Shuhada, and Maqtal Ibn Asir, and great analytical books regarding virtues of Imam Husayn (see: Yūsuf 1998: 54, 70, 91-114, Almāliki n. d.: 152-182, Ibn Jozi 1986: 762-776, Ibn 'Imād 1986: 273-280), wickedness of Yazid, ${ }^{2}$ and grounds and causes of Ashura (Al-Qazvini al-Rāzi 1952: 402-406, Qomi 2004: 329).

Yet, it is not to be forgotten that the mourning for Imam Husayn has created a lot of bloody violence between Shi'a and Sunni over Islamic history. But, the problem was mourning with political purposes ${ }^{3}$ or mourning with heated emotions without attention to its rational aspects. For instance, at the beginning of his government, Mu'izz al-Dawlah (in the Āli Būyah epoch) in Bagdād, commanded his agents to write curses and imprecations to caliphs (the First, Second, and Third) on the top of Dār al-Salām Mosque.

1 It should be recalled that the poems contained non-Shi'a teachings about Imàma and Wilāyā indicates that Sunni poets wrote that. For instance Qāzi Abū Bakr was crying for Imam Husayn but at the same time he believed that Imam had been killed by the sword of Shari'a (ibid.: 100).

2 See Abul-Falāh 'Abd al-Hayy ibn 'Imād who is one of the most remarkable Hanbali's scholars says regarding fault of Yazid: whoever killed Imam Husayn or commanded to kill him or counted that aggression saticfactory, he is an atheist (see: Ibn 'Imād 1986: 274-275, 279-280, Abū 'Ilm 1974: 208-209).

3 This is the reason why a lot of mournings today happen among Sunni people in non-political areas like India, Pakistan, Afghanistan, and Eastern South of Asia (Vāseéi 2009: 252). 
This imprecation resulted in a serious conflict and riot between Shia and Sunni so that Mu'izz al-Dawlah was forced to remove it (see: Al-Shaybāni 1994: 327, Ibn Kasir Damashqi 2008: 81). This kind of conflict is occurring in some Islamic countries at present, in Pakistan, for instance. Nevertheless, the realities such as these could not be a good enough reason to ignore constructive aspects of rational mournings and wise weeping to create real unity and identity among Muslims including laymen and elites. Despite these frustrating realities in the name of Ashura and Imam Husayn, Muslims must reconsider all their texts and whole contexts to reinterpret and reunderstand their tradition and make a peaceful world and society without any violence and controversy across Muslim societies.

\section{III}

\section{Unity in Islamic Identity}

Islamic identity after Ashura could be studied from two perspectives:
A) Political identity in Muslim states;
B) Historical identity in Muslim Ummah.

\section{A) Political Identity in Muslim States}

To speak of Islamic political identity based on Ashura would be possible only if a political system were shaped on political elements and slogans in Ashura. But, neither Shi'a governments nor Sunni ones based their political system on Ashura components. There is no evidence over the Muslim history that Ashura was taken as a cornerstone of their political organization. Political identity would be possible only if Muslim leaders took Ashura as a pattern for political organization. For instance, societal order could be modeled according to Ashura if "sacrifice and heroism" (as central factors of Ashura) were taken into account. And political order could be attributed to Ashura only when it is based on an issue such as "commanding to good and prohibiting from bad (al-amr bi al-ma'rüf va nahy 'an al-munkar)"' that was the key slogan for Imam Husayn in Karbala. Moreover, social identity would be ascribed to Ashura if it came out from components such as the memory of Imam's suffering. ${ }^{2}$ In sum, by the consideration of Ashura as a model of

1 Even though some Ashuraian issues such "commanding to good and prohibiting from bad" had been considered by some caliphs like Mansoor (136-158/753-775), Muhtadi (255-256/840-870), and Ali ibn Sulaymān (169-171/786-788). All these commands and prohibitions were not instituted in social system (see: Cook 2005: 738-740).

2 Regarding "social solidarity based on remembrance of sacred suffering" see: Babaei 2010. 
social and political life, it would be sensible to talk about political or social identity based on Ashura, otherwise, it would be unjustified to attribute political organization to Ashura.

Although Mokhtar's government started with ya la sarat al-Husayn, it was a revengeful state (based on elimination). Also, Shi'a governments such as Ali Buyah and Safawiyyah had serious eagerness to do mourning for Imam Husayn, but they lacked the same idea when establishing their political government according to political features in Ashura.

Yet, I think, the story of Islamic revolution in Iran (1979) had a different story regarding Ashura. Ashura in Iran had decisive role in creation of unity and spiritual energy among nation and politicians. Ashura formed really crucial factor not only in resistance against Pahlawi tyrants before Islamic revolution, ${ }^{1}$ and Saddam Husayn during the eight years of the war between Iran and Iraq, but also in cultural activities, public religiosity, and political decisions in Iran. Iranian leaders tried to activate cultural and political aspects of Ashura in non-warfare situation as well. For instance, the government declared the year of 1381 (solar A. H.) (2002-2003) as "Husaynian Honour Year". Also, the supreme leader of Iran declared the strategy of Karbala as the fundamental strategy against political foreign pressures. There are also some institutions designated for doing the role of commanding to good and prohibiting from bad. In addition, mourning institutions (Haya'at) play a political role in issues such as presidential elections and other political issues in Iran. All this ever-increasing attention to Imam Husayn has constructed Iranian culture so far. Nonetheless, in spite of the great extent of attention to Imam Husayn, it has not yet resulted in political and civilizational region, due to some deep lacks in academic works about Imam Husayn.

\section{B) Historical Identity}

What I mean by historical identity is not identity of a nation in a specific time and place; it is rather an identity that has been formulated through the history. Needless to say that identity emerges from lacking and having. Every identity, including the Islamic identity, has had its own ups and downs in the history. Also, it arises from acceptance (for) and rejection (against). In other words, every kind of identity, whether social or individual, emerges from accepting some things and rejecting some others. Combination of yeses and nos produces a person's or a people's identity. Now, I think Imam

1 To make this fully clear, consider Imam Khumayni example and his comparative words between Islamic revolution and Āshūrā movement. He believes that model of Āshūrā is the best for human revolutions against every kind of oppression and aggressor for ever (see: Imam Khumayni 1995: 60-61). 
Husayn played both positive and negative roles in Ashura to revive and preserve some components and to refuse some others simultaneously over the history of Islam. He posed a brilliant example for the destruction (negative aspect) of tyrannical factors and construction (positive aspect) of tawhidian elements and divine aspects. I believe wherever and whenever Muslims remembered Imam Husayn's tragedy and considered his positive (his heroism) and negative (his suffering and sacrifice) aspects, they could reach an honorable identity even within suffering circumstance.

Although many fractions occurred in the formulation of Muslim identity after Prophet Muhammad, and though the institution of Imama had been neglected by Muslims, Imams did not leave the Ummah alone in their own status. Indeed, according to Shi'a viewpoints, there are, always, human agents (such as Imam or prophet) who preserve the Qur'an from the devil matters. Also, they have the responsibility on behalf of God to implement perfect models of life that is revealed in the Qur'an. Now, I think the role of Imam Husayn was exclusive in creation of Islamic identity through the recognition of the right way from wrong one. Accordingly, Imam declared and preserved the divine path against the devil's ways over the history. Based on this attitude, Imam Husayn was not an individual person, but a quintessential historical figure that carried out the example of divine-man to be a perfect model for the future human generations. Conversely, Yazid was an exculsive example of the historical devil identity. Yazid came from Bani Umayyah while Husayn belonged to the Bani Hashim family. Bani Hashim represented good virtues and self-sacrifice for other human beings, whereas Bani Umayyah symbolized power, politics, and selfishness.

These two groups differed not only in their qualities but also in the physical appearance as well. For instance, Abd al-Mutallib was a handsome white man always surrounded by his ten young children. In contrast, Umayyah was a short, thin, blind man who was led around by his slave (Zuqvan) (see: Al-Aqqād 2008: 85-88).

According to Aqqad (a Sunnit author), differences between these two families in virtue (in Bani Hashim) and vice (in Bani Umayyah), were embodied in different cases. Bani Hashim stayed in Mecca and serviced visitors, but Bani Umayyah visited different cities to provide more money and facility (Abu al-Nasr: 36-38). Bani Hashim, before Prophet Muhammad, were the first in helping righteous wing, in contrast, children of Abd al-Shams engaged in business, presidency, and usury (riba) (see: Al-Aqqād 2008: 85-88). Umayyah considered everything, even religion and prophecy, from a secular approach. ${ }^{1}$

1 After Mecca victory, Bani Umayyah and Abu Sufyan compared the victory of Muhammad with kingdom victory and said to Abbas (Prophet Muhammad's cousin): "What a "great 
However, the conflict between Bani Umayyah and Bani Hashim persisted for a long time until 61/680. in which, the best one (Husayn) from Bani Hashim and the worse one (Yazid) from Bani Umayyah ${ }^{1}$ stood face to face with each other (see: ibid.: 92, 108, Aläeli 1927: 144-147). This tipping point resulted in Imam's martyrdom and Yazid's existence, and in the triumph of Imam's manner of life and failure of Yazid's style of being in Muslim history. These two opposing historical grounds constituted two contrary selves: one (Imam Husayn) is divine and the other (Yazid ibn Mu'awiyah) is wicked and evil. Husaynian self emerged from the golden heritage in which the signs of virtues were clear. In contrast, Yazid's wickedness was the legacy of Bani Umayyah family that fulfilled every kind of evil and depravity (Al-Aqqād 2008: 108).

In sum, these two historical selves carried out two comprehensive models for human being, a brilliant figure that was embodied in Imam Husayn on the one hand, and the wicked one that was implemented in Yazid ibn Mu'awiyah. Because of this universal meta-historical self that was embodied in Husayn, he became an intelligent and wise example for all human beings who take dignity and integrity into account.

Today, Husayn martyrdom can be seen followed greatly in India by three non-Muslim groups: non-Muslim scholars; non-Muslim reformists like Mahatma Gandhi who resisted British colonialism; and non-Muslim mass people. Gandhi said: "I have read Husayn's biography very carefully, and I have understood that there is no way to free oneself from the hands of aggressors other than Husayn's way in Ashura" (Hāshimi-Nizhād 1994: 447). Also, mass people including Muslims and Hindus remember the tragedy of Karbala every year in Muharram. Muslims and non-Muslims in India have a positive experience in creation of social solidarity and national identity through the mourning of Imam Husayn and his suffering and catastrophe in Karbala (Javādi 1994: 447-449).

It should never be lost from sight that for the same reason that has just been mentioned, Imam Husayn was sincerely highly regarded by some Christians also (Hāshimi-Nizhād 1994: 439, 453). Consideration of Ashura by Christians happened in two fields:

A) In academic areas;

B) In mourning rituals.

kingdom this is!". Abbas answered that it was not a kingdom, but a prophethood (see: AlAqqād 2008: 85-88, Khālid 2004: 31).

1 Followers of Mu'awiyah had a flair for politics and consultation, whereas the followers of Yazid were all hunters and torturers. Mu'awiyah, contrary to his son, was patient in dealing with his opponents (ibid.: 115-116). 
There are a lot of Christians who studied Ashura ${ }^{1}$, as well as a great number of Christians in Muslim countries, such as Iran and Lebanon, who participate in the mourning rituals every year.

\section{Conclusion}

By opposing Yazid, Imam Husayn, did not create controversy and conflicts in the Muslim community. Instead, he made a bloody barrier in front of any controversial factor. Insisting on Islamic principles and fundamental values with his on martyrdom Imam locked the doors of deep devision and paved the way for unity and identity among Muslims (including Shi' ite and Sunnit) based on sharia.

Also, he demonstrated a historical manner and model for all human beings who have a genuine desire and willingness to keep righteousness and reject any kind of evil that was embodied in Yazid character. Without this manner and model, Muslims would be unable to tell right from wrong, and differentiate between good and bad. There is no doubt that planning a historical self such as this was very crucial and decisive in protection of Islamic Ummah and Muslim community based on religion and revelation.

Consequently, not only Imam's suffering and martyrdom, but the memory of it also, constituted crucial cause in social solidarity and Islamic Identity. By emphasizing the memory, one can embrace the positive features and avoid the negative ones. Without creating or justifying suffering, the memory of suffering and martyrdom revives past suffering in order to offer instruction and power for the present. Remembrance of spiritual suffering is a reexperiencing of the suffering that is remembered and can result in new emotions and passion. Also, remembrance of sacred sufferings by immediate victims or their descendants can teach and empower them to stand together against those who might create new suffering in the present.

Creation of social solidarity and Islamic identity as a major function of the memory of Imam Husayn's tragedy is not confined to the past but it presents a powerful factor for unity and solidarity for here and now among both Muslim and non-Muslim nations. Whoever, even Christians, recalls this constructive suffering and heroic endurance to preserve

1 This kind of research happened in several ways including translation of Maqtals in English and German, Āshūrā history, analytic texts from different perspectives like: Fatima et les filles De Mahomet, by Henry Lammens, Ta'ziyah: Ritual and Drama in Iran, and From Karbala to New Yok City: Ta'ziyah on the Move, by P. Chelkowski, and Al-Husayn fi Fikr al-Masihi, by Antowan Bara (see: Husayni 2009: 87-128). 
self-honour and dignity, will be able to make association with others who share the same honour and dignity.

Received: March 1 $1^{\text {st }}, 2013$

Accepted: April 5 $5^{\text {th }}, 2013$

\section{References}

Abu al-Nasr, Omar, Zendegiye Seyyedo al-Shohadā, Translated by Seyyed Ja'far Gazbān, Majalleh Mahe No Press.

Abū Elm, Tofig (1974), Al-Husayn ibn Ali, Cairo, Dār al-Ma’ārif.

Āeinehvand, Sādiqh (1988), Imam va Giyāmhāyeh Shi'e dar Tärikhe Islam, Tehran, Sipāh Pāsdaran Ingelābe Islami Press.

Al-Aqqād, Abbās Mahmūd (2008), Abu al-Shuhadā, al-Husayn ibn Ali, Searched by Muhammad Jāsim al-Sāédi, Tehran, Al-Majma’ al-ālami li al-Taqrib Bayn al-Mazāhib al-Islāmiyyah.

Al-Amin al-Hussayni al-Āmili, Sayyid Muhsin (2003), Kashfu al-Irtiyāb fi Atbāi Muhammad ibn 'Abdu al-Vahhāb, Dar al-Kutub al-Islamiyya.

Al-Amin, Sayyid Muhsin (1986), A’ayān al-Shi'ah, Beirut, Dar al-Ta’āruf li al-Matbü'āt, Vol. 1.

Al-Andalusi, Ibn Jabir (1985), Al-Hillah al-Seirā fi Madhi Khair al-Varā, Researched by Ali Abū Zayd, Beirut/Damascus, 'Alam al-Kutub Press.

Al-Ghazvini al-Rāzi, Abd al-Jalil (1952), Kitāb al-Naqz, Tehran, Anjoman Asar Melli.

Al-Shaybāni, 'Izz al-Din abul-Husayn 'Ali ibn abi al-Karam (Ibn al-Ásir) (1994), Al-Kämil fi al-Tarikh, Volume 5, Lebanon, Beirut, Mu’assisah al-Tārikh al-Arabi.

Al-Tu’mah, Salmān Hādi (1964), Turās Karbala, Beirut, Mu’assisah al-'Alami li al-Matbü’àt.

Alāeli Misri, Abdullāh (1927), Al-Imām al-Husayn, Sumuww al-Mảnā fi Sumuww al-Zāt - Ashiatun min Hayāt al-Husayn, Beirut, Dār al-Maktaba al-'Arabiyyah.

Alāeli Misri, Abdullāh (1945), Târikh Husayn ibn 'Ali, Translated by Kamrehi, Tehran, Sherkate Sahāmi Chāp Farhang Iran.

'Ali, Sayyid Amir (1938), Mukhtasar Tārikh al-Arab va al-Tamaddun al-Islami, Cairo, Lujna al-Ta'lif va al-Tarjumah va al-Nashr.

Almāliki (Ibn al-Sabbāgh), Ali ibn Muhammad ibn Ahmad (n. d.), Al-Fusūl al-Muhimmah fi Márifati Ahavāl al-A'immah, Najaf, Maktabah Dār al-Kutub al-Tijāriyyah, Matba'a al-'Adl.

Babaei, Habibollah (2010), "A Shi' ite Theology of Solidarity through the Remembrance of Liberative Suffering," in The Ecumenical Studies, USA, Temple University. 
Cook, Michael (2005), Amre be Ma'rūf va Nahy az Monkar dar Andisheye Islami (Commanding Right and Forbidding Wrong in Islamic Thought), Translated by Ahmad Namāei, Mashhad, Bonyāde Pazhūheshhāye Islami Āstāne Razavi Press.

Hāshimi-Nizhād, Sayyid Abul-Karim (1994), Darsi ke Husayn be Insānhā Āmūkht, Tehran, Moa'sseseh Farāhāni Press.

Husayni, Golām Ehyā (2009), "Ashura Pazhūhi dar Garb”, in Journal of Tārikh Islam 10 (1): 87-128.

Ibn 'Imād (Shahāb al-Din abi al-Fallāh 'abd al-Hayy ibn Ahmad ibn Muhammad al-'Akri al-Hanbali al-Damashqi) (1986), Shazarāt al-Zahab fi Akhbāri man Zahab, Volume 1, Researched by 'Abd al-Qadir and Muhammad al-Arnāvūt, Beirut/Damascus, Dār Ibn Kasir.

Ibn Jozi, Abul-faraj (1986), Sifato al-Safvah, Volume 1, Lebanon, Beirut, Dar al-Ma'rifah.

Ibn Kasir Damashqi, Abi al-Fidā al-Hāfiz (2008), Al-Bidāyah wa al-Nihāya, Beirut, Markaz al-Sharq al-Awsat al-Siqāfi.

Ibn Khaldūn, Abd al-Rahmān (1983), Muqaddamah Ibn Khaldūn, Translated by Parvin Gonābadi, Tehran, Elmi va Farhangi Press.

Imam Khumayni, Sayyid Rūhollāh (1995), Qyāme Ashura dar Kalām va Payāme Imām Khumayni, Tehran, Moasseseh Tanzim va Nashre Āsāre Imām Khumayni.

Ja'fari, Sayyid Husayn Muhammad (1999), Tashayyo' dar Islam, Tahlil va Barrasi Elal va Seire Takvin ān dar Islam, Translated by Muhammad Taqi Āyatollāhi, Tehran, Daftar Nashr Farhange Islami Press.

Javādi, Sadr Hāj Sayyid, and colleagues (1994), Encyclopedia of Tashayyo', Volume 4, Tehran, Elmi va Farhangi Press.

Khālid, Khālid Muhammad (2004), Abnä’ al-Rasūl fi Karbala, Cairo, Dār al-Maqtam li al-Nashr wa al-Tawzi'.

Khizri Bak, Muhammad (1963), Muhāzirāt Tārikh al-Umam al-Islāmiyyah, Volume 2, Cairo, Maktaba al-Tijāriyyah al-Kubrā Press.

Macci, Muhammad Ali, Omar Mūsā, 'Izz al-din (1997), Tashayyo' dar Andalusia, Translated by Rasūl Ja’fariyān, Qom, Ansāriyan Press.

Majlisi, Muhammad Bāqir (1983), Bihār al-Anwār, Lebanon, Beirut, Mu’assisah al-Vafā, Dār Ihyā al-Turās al-'Arabi.

Massignon, Louis (1982), The Passion of al-Hallaj, Mystic and Martyr of Islam, Volume 3, Translated from French with a biographical foreword by Herbert Mason, Princeton, New Jersey, Princeton University Press.

Mazāhiri, Muhsin Hisām (2008), Rasāneye Shi’a, Jāme’eh Shināsi Āeenhāye Sūgvāri va Heiathāye Mazhabi dar Iran bā Ta’kid bar Dorān pas az Engelābe Islami, Tehran, Sāziman Tabligāte Islami, Sherkate Chāp va Nashre Beinolmelal.

Muzaffar, Muhammad Husayn (1987), Tārikh al-Shìa, Lebanon, Beirut, Dār al-Zahra.

Qomi, Shaikh Abbās (2004), Tatimma al-Muntahā fi Tārikh al-Khulafā, Qom, Maktabah al-Fadak wa Maktabah al-Safā. 
Sāeib, Abdul-Hamid (1997), Ibn Taymiyyah, Hayātuhu wa 'Aqāiduhu, Qom, Markaz al-Ghadir li al-Dirāsāt al-Islāmiyyah.

Salimi, Heshmatollāh (2007), Mobārezāt Rūhāniyūn va Vơàze Masājed be Revāyat Asnād, Tehran, Markaze Asnāde Inqelābe Islami Press.

Sāziman Pazhūhesh va Barnāme Rizi Āmūzeshi (2001), Tarikh Imam Husayn, Mousūeye Imam Husayn, Tehran, Daftar Enteshārāte Komak Āmūzeshi.

Sharaf al-Din, Abd al-Husayn (1972), Falsafeye Shahādat va Azādāri Husayn ibn Ali, Translated by Ali Sihhat, Tehran, Mortazavi Press.

Tabari, Abi Ja’far Muhammad Jarir (1987), Tārikh al-Tabari, Tärikh al-Umam wa al-Mulūk, Volume 5, Beirut, Lebanon.

Vāseéi, Alirezā, and colleagues (2009), Negahi No be Jarayāne Ashura, Qom, Būstāne Ketāb Press.

Yūsuf, Husayn Muhammad (1998), Sayyidu Shabābi Ahl al-Jannah, Ibnu Binti Rasūlullah, Cairo, Dār al-Sha’b.

Zandi Hanafi Madani, Jamāl al-Din Muhammad Yūsuf ibn Muhammad (n. d.), Nazm al-Durar al-Samtin fi Fazāil al-Mostafā wa al-Batūl wa al-Sibtayn, Tehran, Maktabah Naynavā al-Hadisah. 